\title{
PEMBERIAN BANTUAN KEMANUSIAAN KORBAN BENCANA BANJIR DI KABUPATEN ACEH UTARA
}

\author{
M. Saleh ${ }^{1}$, Cut Khairani ${ }^{2}$, Hakim Muttaqim ${ }^{3}$, M. Rasyidin ${ }^{4}$, Nova ${ }^{5}$ \\ 1345 Dosen Prodi. Ekonomi Pembangunan Fakultas Ekonomi Universiats Almuslim \\ ${ }^{2}$ Dosen Prodi. Administrasi Publik FISIP Universitas Almuslim \\ Email: muhammadsaleh286@gmail.com, cut.fisip13@gmail.com, \\ hakimmuttaqim11@gmail.com,m_rasyidin@yahoo.com,novasyamaun1@gmail.com
}

\begin{abstract}
ABSTRAK
Kegiatan Pengabdian Kepada Masyarakat (PKM) yang dilakukan oleh tim PKM Univesitas Almuslim berupa pemberian bantuan kemanusiaan korban bencana banjir di Kabupaten Aceh Utara. Desa-desa yang terendam banjir berada di Kecamatan Simpang Keuramat Pirak Timu Matangkuli Lhoksukon Tanah Luas dan Syamtalira Bayu. Pemberian bantuan dilaksanakan pada daerah rawan banjir dengan mengambil lima titik lokasi. Lokasi ini dipilih atas pertimbangan kondisi dan karakteristik daerah rawan banjir, yang dicirikan dengan perbedaan intensitas banjir, jumlah dan kepadatan penduduk, serta keandalan. Simpulan yang diperoleh setelah kegiatan PKM ini adalah: 1) bantuan kebutuhan pokok masyarakat sebagai salah satu kebutuahan masih sangat kurang; 2) kebijakan pemerintah daerah tentang penanggulangan bencana masih sangat terbatas; 3) peraturan perundang-undangan, terutama di daerah masih terbatas; 4) pendanaan penanggulangan bencana masih sangat tergantung dari Anggaran Pendapatan Belanja Negara (APBN) dan Anggaran Pendapatan Belanja Daerah (APBD). Berdasarkan kajian ini direkomendasikan bahwa perlu ditetapkan lebih cermat tingkat partisipasi pada setiap tahap kegiatan, sesuai dengan jenis kegiatan penanggulangan banjir. Kemudian perumusan kebutuhan bantuan kemanusiaan kepada korban banjir dapat dilakukan dengan rekomendasi kepala desa setempat.
\end{abstract}

\section{Kata Kunci: bantuan kemanusiaan, korban bencana banjir}

\begin{abstract}
The community service activity carried out by the team this time is the provision of humanitarian assistance to flood victim in North Aceh district. The villages that were flooded were in Simpang Keuramat, Pirak Timu, Matangkuli, Lhoksukon, Tanah Luas and Syamtalira Bayu sub-districts. The provision of assistance is carried out in floodprone areas by taking five locations. This location was chosen based on the consideration of the conditions and characteristics of the flood-prone areas, which are characterized by differences in flood intensity, population and population density, and reliability. The conclusions that can be drawn are: (1) Assistance for essential needs of the community as one of the basic needs is still very lacking; (2) local government policies on disaster management are still very limited; (3) laws and regulations, especially in the regions, is still limited; (4) Disaster management funding is still very dependent on the State Budget (APBN) and Local Government Budget (APBD). Based on this study, it is recommended that it is necessary to determine the level of participation at each stage of activity more carefully, according to the type of flood prevention activities. Then the formulation of the need for humanitarian assistance to flood victims can be done with the recommendation of the local village headman.
\end{abstract}




\section{Key Words : flood disaster victims, humanitarian assistance}

\section{PENDAHULUAN}

Banjir tidak hanya menyebabkan sawah tergenang dan meluluhlantakkan perumahan dan permukiman, tetapi merusak fasilitas pelayanan sosial ekonomi masyarakat dan prasarana publik, bahkan menelan korban jiwa. Kerugian semakin besar jika kegiatan ekonomi dan pemerintahan terganggu atau terhenti. Meskipun partisipasi masyarakat dalam rangka penanggulangan banjir sangat nyata, terutama pada aktivitas tanggap darurat, namun banjir menyebabkan tambahan beban keuangan negara, terutama untuk merehabilitasi dan memulihkan fungsi prasarana publik yang rusak. Selain kerugian yang bersifat material, banjir menyebabkan kerugian non material, berupa kerawanan sosial, wabah penyakit, menurunnya kenyamanan lingkungan, serta menurunnya kesejahteraan korban banjir yang mengakibatkan kegiatan perekonomian terhambat.

Oleh karena itu, tim Pengabdian kepada Masyarakat (PKM) Universitas Almusim Peduli mendistribusikan bantuan kemanusiaan terhadap kebutuhan pokok untuk korban bencana banjir atas rekomendasi kepala desa setempat. Adapun dalam kegiatan PKM ini, tim PKM Universitas Almuslim Peduli bekerjasama dengan Yayasan Khairul Ummah Berbagi. Kegiatan PKM yang dilaksanakan oleh tim berupa pemberian bantuan kemanusiaan untuk korban bencana banjir di Kabupaten Aceh Utara. Desa-desa yang mulai terendam banjir yaitu desa yang berada di Kecamatan Simpang Keuramat, Pirak Timu, Matangkuli, Lhoksukon, Tanah Luas dan Syamtalira Bayu.

Adapun tujuan kegiatan PKM ini adalah memberikan bantuan kemanusiaan kepada korban banjir, sehingga dapat meringankan beban yang dihadapi. Sedangkan, hambatan yang ditemukan dalam proses pelaksanaan kegiatan ini, yaitu keterbatasan ketersediaan barang dan akses bantuan pihak lain.

Adapun output yang diharapkan dalam kegiatan ini adalah terdistribusinya bantuan yang telah digalang kepada para korban banjir. Lalu, outcomes yang diperoleh dari kegiatan PKM berupan pemberian bantuan kemanusian bagi banjir di Kabupaten Aceh Utara, adalah: 1) bantuan kemanusian akibat banjir diharapkan dapat meningkatkan 
pengetahuan dan kesadaran akan pentingnya kepedulian untuk meringankan beban secara bersama; dan 2) merupakan implementasi dari Tri Dharma Perguruan Tinggi berupa pengabdian kepada masyarakat yang dilakukan oleh tim dosen Universitas Almuslim, yang memiliki kepedulian terhadap korban bencana alam, khusunya korban banjir di Kabupaten Aceh Utara. Bahkan, bentuk pengabdian ini dirasakan manfaatnya bagi para korban. Sedangkan, target luaran yang dihasilkan dari pelaksanaan kegiatan pemberian bantuan kemanusiaan berupa publikasi pada jurnal pengabdian kepada masyarakat ber-ISSN, baik cetak maupun online.

\section{METODE PELAKSANAAN}

Kegiatan Pengabdian kepada Masyarakat berupa pemberian bantuan kemanusiaan untuk korban bencana banjir di Kabupaten Aceh Utara dilakukan melalui beberapa tahap, sebagai berikut: 1) persiapan, yaitu (a) menghubungi tim mitra Yayasan Khairul Ummah Berbagi, (b) pengurusan administrasi, (c) persiapan alat dan bahan serta akomodasi, (d) persiapan logistik bantuan, dan (e) penentuan titik distribusi bantuan, yang dilakukan selama 2 (dua) hari; 2) pelaksanaan, yaitu kegiatan distribusi bantuan kemanusiaan tersebut dilakukan pada sore hari selama 1 (satu) hari; dan 3) penutupan, berupa pemberian bantuan, foto bersama dan kembali ke Kampus Universitas Almuslim Matangglumpang dua (1 hari).

\section{HASIL DAN PEMBAHASAN}

Menurut Badan Nasional Penanggulangan Bencana (BNPB) (2020), menyatakan bahwa Indonesia dengan berbagai kondisi geologis dan geografisnya sangat rentan terhadap bencana, bahkan Indonesia disebut sebagai supermarket bencana. Banjir merupakan bencana yang paling berpotensi terjadi saat curah hujan tinggi. Penanggulangan bencana dilakukan dengan menjalankan menajamen bencana yang terdiri atas tahap-tahap berikut: 1) sebelum bencana terjadi, meliputi pencegahan, mitigasi, kesiapsiagaan dan kewaspadaan; 2) pada waktu bencana sedang atau masih terjadi, meliputi peringatan dini, penyelamatan, pengungsian dan pencarian korban; 3) sesudah terjadi bencana, meliputi penyantunan dan pelayanan, konsolidasi, rehabilitasi, pelayanan lanjut, penyembuhan, rekonstruksi dan pemukiman kembali penduduk. 
Menurut Rinawati, dkk,. (2018), menyatakan bahwa manajemen logistik untuk penanggulangan bencana dikenal dengan logistik kemanusiaan (humanitarian logistics) atau disebut juga logistik bantuan kemanusiaan. Humanitarian logistics merupakan kegiatan perencanaan, pelaksanaan, pengendalian aliran bantuan hemat biaya dari titik asal ke korban untuk tujuan mengurangi beban penderitaan korban bencana.

Berdasarkan wawancara dengan korban bencana, disimpulkan bahwa distribusi bantuan sosial oleh tim dosen Universitas Almuslim dan tim mitra Yayasan Khairul Ummah Berbagi sudah cukup membantu korban bencana, terlihat dari respon yang diberikan korban terkait distribusi bantuan sosial tersebut. Respon yang baik menandakan bahwa pendistribusian bantuan sosial berdampak positif dalam meringankan beban korban.

Berikut merupakan dokumentasi kegiatan selama proses pendistribusian bantuan korban banjir di Kabupaten Aceh Utara:

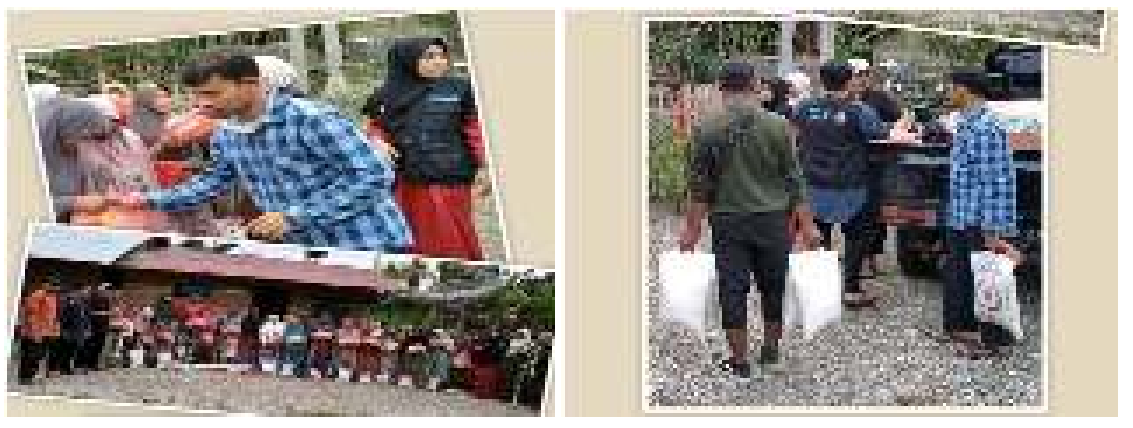

\section{Gambar Kegiatan Pendistribusian Bantuan Sosial Korban Banjir}

Gambar 1 di atas memperlihatkan kegiatan yang dilakukan oleh tim PKM Universitas Almuslim dan Yayasan Khairul Ummah Berbagi saat pendistribusian bantuan di titik lokasi terjadinya banjir. Kegiatan ini disambut dengan antusias oleh korban bencana.

\section{KESIMPULAN DAN SARAN}

Kegiatan pendistribusian bantuan kemanusiaan untuk korban bencana banjir oleh tim PKM Universitas Almuslim dan Yayasan Khairul Ummah Berbagi telah memberi manfaat yang signifikan. Pemilihan jalur dari lokasi pengiriman barang (titik pasok) menuju titik permintaan yaitu posko pengungsian di Aceh Utara berlangsung cepat dan tepat sasaran. Adapun dalam proses distribusi bantuan diperlukan rekomendasi pihak 
perangkat kepala desa dalam penentuan jalur mana yang akan dilewati transportasi distribusi bantuan ke tempat pendistribusian. Lalu, penentuan komoditas barang bantuan yang dihasilkan melalui hasil rekomendasi kepala desa dalam distribusi bantuan logistik kemanusiaan di Kabupaten Aceh Utara memiliki komoditi yang tidak terpenuhi dengan nilai rata-rata $87 \%$ berakibat lebih kecilnya jumlah bantuan dibandingkan jumlah korban banjir. Pemberian bantuan logistik kemanusiaan yang dapat dikirimkan ke Kabupaten Aceh Utara yang paling optimum dipilih untuk mendistribusikan barang bantuan logistik kemanusiaan ini adalah melalui Lhokseumawe dengan perhitungan jarak yang lebih dekat dan kondisi iklim seperti hujan yang lebih aman.

Adapun saran yang disampaikan setelah kegiatan pengabdian ini adalah: 1) hendaknya kegiatan serupa dilakukan secara kontinyu terhadap korban bencana banjir; dan 2) menjalin kerjasama dengan pihak mitra dalam proses distribusi bantuan kepada korban bencana banjir.

\section{UCAPAN TERIMA KASIH}

Terima kasih terhadap tim mitra Yayasan Khairul Ummah, pihak penyumbang bantuan dan pihak lain yang memberikan rekomendasi persiapan tempat titik distribusi bantuan.

\section{REFERENSI}

https://www.cnbcindonesia.com/news/20200305205046-4-142854/bnpb-indonesiasupermarket-bencana-tapi-jangan-kecil-hati, diakses tangal 9 Juli 2021.

Rinawati, I.D., Sari, P.D., Priatamphatie, F., Fahrudin. 2018. Rancang Bangun Sistem Informasi Bantuan Logistik Bencana Studi Kasus pada BPBD Kabupaten Magelang. Semarang: Teknik Industri dan Geologi Fakultas Teknik Universitas Diponegoro. 